\title{
Improved isolation of good-quality total RNA from the optic stalk of Mud crab, Scylla paramamosain
}

\author{
Houze Zhu' ${ }^{1}$ Keji Jiang ${ }^{2} \cdot$ Fengying Zhang ${ }^{2} \cdot$ Dan Zhang ${ }^{2,3} \cdot$ Yan Pi $\square^{1} \cdot$ Lingbo Ma $\square^{2}$ \\ 1 Fudan University, School of Life Sciences, Shanghai, China \\ 2 Chinese Academy of Fishery Sciences, East China Sea Fisheries Research Institute, Shanghai, China \\ 3 College of Fisheries and Life Science, Shanghai Ocean University, Shanghai, China \\ $\triangle$ Corresponding authors: yanpi@fudan.edu.cn; malingbo@vip.sina.com \\ Received October 7, 2011 / Accepted January 12, 2012 \\ Published online: March 15, 2012 \\ (C) 2012 by Pontificia Universidad Católica de Valparaíso, Chile
}

\begin{abstract}
An improved and efficient protocol was developed based on the TaKaRa RNAiso Plus Kit (Code: D9108A) for isolating good-quality total RNA from the optic stalk of mud crab, Scylla paramamosain. The protocol was based on the Trizol method with modifications. The carapace overlapping the optic stalk was retained with RNA in regular protocol. In order to remove the abundant deposition correlative with the carapace which makes the isolation of RNA particularly difficult, 5M potassium acetate solution $(\mathrm{pH}=6.0)$ was added before the precipitation of RNA, and the temperature of RNA deposition was also decreased to $-70^{\circ} \mathrm{C}$ to ensure the stabilization of RNA. Good-quality total RNA from the optic stalk of $S$. paramamosain could be easily isolated with this modified protocol and three conventional methods were also employed to confirm the quality of RNA. This improved method would be helpful in facilitating molecular research of crabs involving RNA from the optic stalk.
\end{abstract}

Keywords: optic stalk, potassium acetate, RNA isolation, Scylla paramamosain

\section{INTRODUCTION}

Scylla paramamosain is a mud crab found throughout Vietnam (Dahdouh-Guebas et al. 2006), Taiwan island and southeast coasts of China (Zeng and Li, 1999). On previous researches of crustacean, there were peptide hormone genes that transcript in the X Organ-Sinus Gland Complex located in optic stalk as which belong to specific new crustacean hormone family (Chang, 1993) including a number of neural peptides such as $\mathrm{CHH}$ (De Kleijin et al. 1998), MIH (Gu et al. 2000) and GIH (Udomkit et al. 2000). Research of these peptide families would be relevant to the cultivation about crustacean aquatic product such as Carcinus maenas (Nakatsuji et al. 2009), Scylla olivacea (Tsai et al. 2008), and red rock crabs (Hsu et al. 2008). What's more, the establishment of cDNA library of S. paramamosain is elementary to the study of this species and there is hardly any data about the cDNA of $S$. paramamosain optic stalk. In a word, extracting high quality total RNA from the optic stalk becomes impendent and essential.

As the isolation itself is based on small dose with a few optic stalks, the common protocol with hexadecyltrimethylammonium bromide and polyvinylpolypyrrolidone (Liao et al. 2004; Rubio-Piña and Vázquez-Flota, 2008; Rubio-Piña and Zapata-Pérez, 2011), or sodium dodecyl sulfate (Rai et al. 2010) for plants is not very applicable to stalks as it is suitable for removing polysaccharides and polyphenols. While Trizol, a current RNA protocol will be an appropriate protocol with advantage in small dose and high quality and it is frequently used in RNA isolation (Chadderton et al. 1997; Gehrig et al. 2000; Bovée et al. 2001). It has been used particularly in RNA extraction on diverse organism of $S$. paramamosain (Imjongjirak et al. 2009; Liu et al. 2010; Xu et al. 2011) yet optic stalk. As eyestalks are overlapped with carapace and there can be remaining of partial facetted carapace after the cleave 
separation of stalk from eyes, isolating of total RNA from optic stalk with traditional Trizol method will obtain abundant ivory-white insoluble semisolid intermixed with RNA. Apart from that, RNase which exists surrounding the situation is a fatal interference during extraction to decompose the RNA. In a word, the isolation sample via traditional Trizol protocol is unqualified to get further use in ensuing experiments. So an easy and efficient modified protocol was developed for isolating good-quality total RNA from the optic stalk of S. paramamosain based on Trizol method with some other modifications.

\section{MATERIALS AND METHODS}

\section{Management of instruments}

Mortars, mullers, and other metal appliances including ophthalmic scissors, medicine spoon and tweezers were treated with $0.1 \%$ DEPC solution at $37^{\circ} \mathrm{C}$ overnight, autoclaved twice at $121^{\circ} \mathrm{C}$ for 20 $\mathrm{min}$, and dried at $100^{\circ} \mathrm{C}$ then refrigerate at $-70^{\circ} \mathrm{C}$ before use. Tips, reagent bottles and centrifuge tubes used in RNA extraction were RNase free. The Beckman Counter Allegra 64R centrifuge was used in centrifugation.

\section{RNA isolation reagent}

The experiment was based on TaKaRa RNAiso Plus (Takara code: D9108A, Shiga, Japan), a representative Trizol reagent, as it is a currently used RNA isolation kit which is effective in extracting RNA from most tissues including plants and animals (Chirgwin et al. 1979; Nicolaides and Stoeckert, 1990). In general, $600 \mu \mathrm{l}$ of reagent was put in a $1.5 \mathrm{ml}$ centrifuge tube and the operation was accomplished in RNase-free situation (ventilation board).

\section{Other reagents}

$5 \mathrm{M}$ potassium acetate (Sinopharm Chemical Reagent, Shanghai, China) solution with 0.1\% DEPCtreated water (Xufei, Shanghai, China) and potassium acetate in solid was deployed then a few drops of glacial acetic acid (Sinopharm Chemical Reagent, Shanghai, China) would be accessed to dissolve the acetate to decrease the $\mathrm{pH}$ value to 6 in solution. $75 \%$ enthanol (Sinopharm Chemical Reagent, Shanghai, China) with $0.1 \%$ DEPC-treated water was also configured. Chloroform and isopropyl alcohol (Sinopharm Chemical Reagent, Shanghai, China) in analytical cure were prepared for this experiment. All reagents were prepared in ventilation board to assure an RNase-free environment.

\section{Tissue materials}

One eyestalk (0.50-0.70 g) with compound eye was taken down from a mature S. paramamosain (weighed as $0.55-0.65 \mathrm{Kg}$ ), then the compound eye were cut off with ophthalmic scissors above each stalk and the eyestalk was put into a mortar filled with liquid nitrogen which was used to quickly freeze the situation. The optic stalk was ground in the mortar and pulverous tissue was transferred into two centrifuge tubes with $600 \mu \mathrm{l}$ of TaKaRa RNAiso reagent to start this experiment immediately. For these two tubes, one is marked with $A$ and the other is marked with $B$. In tube A, we used the protocol on Takara instruction as control. In tube $\mathrm{B}$, we used the modified protocol as experimental group. There would be a contrast in control and experimental group to reflect the isolating efficacy on ordinary protocol and modified protocol. All the operations were processed in ventilation board to assure an RNase-free environment.

\section{RNA extraction procedure}

Isolation of total RNA was based on Trizol method with melioration. The experiment was carried out in triplicate repeats with eyestalks from separate crabs to make sure the improvement in protocol is creditable. Stalk tissue was ground into pulverous in liquid nitrogen and scraped into two $1.5 \mathrm{ml}$ centrifuge tubes which contained $600 \mu \mathrm{l}$ of RNAiso Plus. Each tube contained about half an optic stalk volume of comminuted stalk tissue. Each centrifuge tube was shocked intensively for 15 sec to mix the contents and kept still for 5 min then the tubes were centrifuged at 12,000 g (Beckman Coulter Allegra $64 \mathrm{R}$ centrifuge) at $4^{\circ} \mathrm{C}$ for $5 \mathrm{~min}$. Liquid in each tube was accumulated and then transferred to a new 
$1.5 \mathrm{ml}$ tube and chloroform as one fifth volume of the liquid contents was subsequently added in the new tube. Subsequently, the contents in each new tube were vibrated emphatically until whose colour in the tube turned into oyster white, and then the tubes were centrifuged at $12,000 \mathrm{~g}$ at $4^{\circ} \mathrm{C}$ for $15 \mathrm{~min}$. There were three liquid phases and the supernatant phase of each tube was transferred to a new 1.5 $\mathrm{ml}$ tube which is still marked with $\mathrm{A}$ or $\mathrm{B}$ following the previous tubes. Subsequently, $5 \mathrm{M}$ potassium acetate $(\mathrm{pH}=6.0)$ as one third volume of the accumulated liquid was added in tube $\mathrm{B}$ and $0.1 \%$ DEPCtreated water in tube $A$ with the same volume as acetate solution. Contents in tubes were then mixed with rapid centrifugation $\left(5,000 \mathrm{~g}\right.$ at $4^{\circ} \mathrm{C}$ for $\left.1 \mathrm{~min}\right)$ and set still for $5 \mathrm{~min}$. In the ensuing step, isopropyl alcohol in analytical pure as one volume of the mixture was added and vibrated thoroughly, then those centrifuge tubes were frozen at $-70^{\circ} \mathrm{C}$ for $30 \mathrm{~min}$ to precipitate the total RNA in the mixed solution. Afterwards, tubes were taken out and centrifuged at $12,000 \mathrm{~g}$ at $4^{\circ} \mathrm{C}$ for $10 \mathrm{~min}$. Only the deposition in each tube was kept, and then washed with $1000 \mu \mathrm{l}$ of $75 \%$ ethanol (with $0.1 \%$ DEPC-treated water) in each tube. Tubes were centrifuged at $5,000 \mathrm{~g}$ at $4^{\circ} \mathrm{C}$ for $3 \mathrm{~min}$ and only the deposition was kept and then dried in the ventilation board until no droplet could be seen in the tubes. The obtained sediment was re-dissolved in each tube with $20 \mu \mathrm{l}$ of $0.1 \%$ DEPC-treated water and stored at $-70^{\circ} \mathrm{C}$ for further use.

\section{Agarose gel electrophoresis}

After thawing, $1 \mu \mathrm{l}$ of extractive solution was imbibed from each tube and mixed with $1 \mu \mathrm{l}$ of 6 x loading buffer (BAOMAN BIOTECHNOLOGY, code: GH101-01, Shanghai, China) respectively. Next, those samples and $2 \mu \mathrm{l}$ of DNA marker (TaKaRa DL2000, Takara code: D501S, Shiga, Japan) were contrasted on 1.5\% agarose gel (Biowest, Spain) which contained 0.02\% EB (Tiangen, Beijing, China). Agarose gel was functioned on $120 \mathrm{~V}$ in $30 \mathrm{~min}$ and observed on the UV spectra photometer (FR200A).

\section{UV $260 / 280 \mathrm{~nm}$ ratio test}

The test of $260 / 280 \mathrm{~nm}$ ratio of solution in tube A and tube B were performed with Beckman Counter DU800. In the first instance, one drop $(0.5 \mu \mathrm{l})$ of $0.1 \%$ DEPC water was applied to proofread instrument error of machine. Then the $260 / 280 \mathrm{~nm}$ ratio of solution in tube $A$ and tube $B$ were examined three times for each as one time in $0.5 \mu$ following the manufacturer's instruction.

\section{Analysis of the production with RT-PCR}

As the ultimate purpose of this study is to isolate total RNA from tissue, the most direct method to examine total RNA is to examine the cDNA which is the reverse transcription product of RNA. Reference genes of $S$. paramamosain were chosen genes for the detection. The primer for reverse transcription were designed based on the gene sequences coding ubiquitin conjugating-enzyme E2 (S. paramamosain ubiquitin-conjugating enzyme E2 mRNA, GenBank: FJ265877.1) and $\beta$-actin gene (S. paramamosain beta-actin mRNA, GenBank: GU992421.1), as shown in Table 1. TaKaRa One Step RNA PCR Kit ver. 3.0 (Takara code: DRR019A, Shiga, Japan) was used following the instructor of reagent protocol. The obtained substances in tube $A$ and tube $B$ were used as template $(1 \mu l$ of RNA solution in $50 \mu \mathrm{l}$ of reaction solution) with the designed primers separately. The reaction solution was bathed at $50^{\circ} \mathrm{C}$ for $30 \mathrm{~min}, 94^{\circ} \mathrm{C}$ for $2 \mathrm{~min}$, followed by 28 cycles of amplification $\left(94^{\circ} \mathrm{C}\right.$ for $30 \mathrm{sec}, 55^{\circ} \mathrm{C}$ for $30 \mathrm{sec}$, and $72^{\circ} \mathrm{C}$ for $1 \mathrm{~min}$ ). After all the reactions, RT-PCR products were inspected through agarose gel electrophoresis as $5 \mu \mathrm{l}$ of resultant with $5 \mu \mathrm{l}$ of $6 \times$ loading buffer, and $8 \mu \mathrm{l}$ of DNA marker (TianGen code: MD105, Beijing, China) was employed as DNA size reference. Sequencing was also performed to confirm the sequence of these two genes.

Table 1. The forward primers and the reverse primers of two family genes chosen to identify the existence of RNA in the substance in tube $A$ and tube $B$.

\begin{tabular}{ll}
\hline \multicolumn{1}{c}{ Primer Name } & \multicolumn{1}{c}{ Sequence (5' to $\mathbf{3}^{\prime}$ ) } \\
Sp Ubiquitin conjugating enzyme E2 forward & GGG CAG TGT CGC ATT CTA TTC CTT C \\
Sp Ubiquitin conjugating enzyme E2 reverse & TGA GAA GGT CCT GAA TTC CCA AAA GA \\
Sp $\beta$-actin protein forward & CTG ATA ATC AGT CGA TGG AAA ATT CAC CAC \\
Sp $\beta$-actin protein reverse & TCA TCT TTT CGC GGT TGG CCT T \\
\hline
\end{tabular}




\section{RESULTS}

\section{Extraction of RNA}

Comminuted stalk tissue were put in centrifuge tubes with RNAiso Plus, after vibration and remaining for a time, there was a lot of sedimentation attached on the inner wall of centrifuge tube (Figure 1) and the supernatant was kept. Later at the precipitation of RNA after adding isopropyl alcohol and remaining in hypothermia, abundant ivory-white deposition appeared on the inner wall of tube $A$ while a little translucent sedimentation on the inner wall of tube B (Figure 2). The substance in tube A could not be all dissolved in $20 \mu \mathrm{l}$ of $0.1 \%$ DEPC-treated water, yet $20 \mu \mathrm{l}$ of $0.1 \%$ DEPC-treated water dissolved all substance in tube $B$.

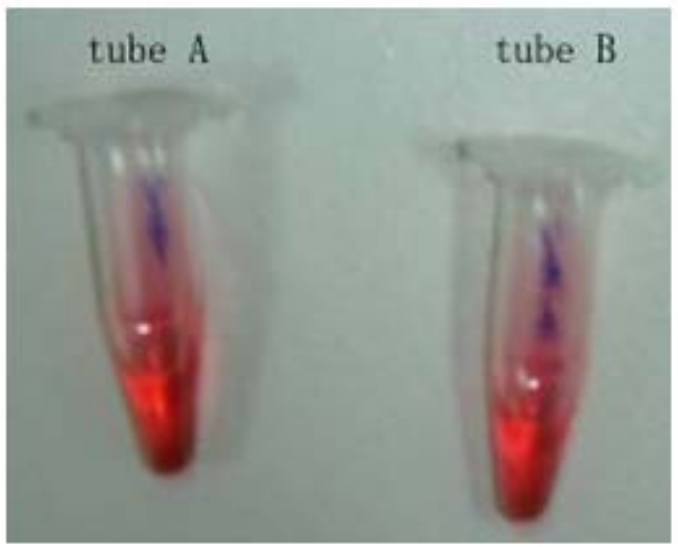

Fig. 1 Precipitation in the tubes during experiment. There is no evident difference between tube $A$ (control group) and tube B (experimental group), and both the tubes have precipitation on the inner wall of itself, as RNA is dissoluble, deposition on the inner wall is useless for ensuing experiment and discarded.

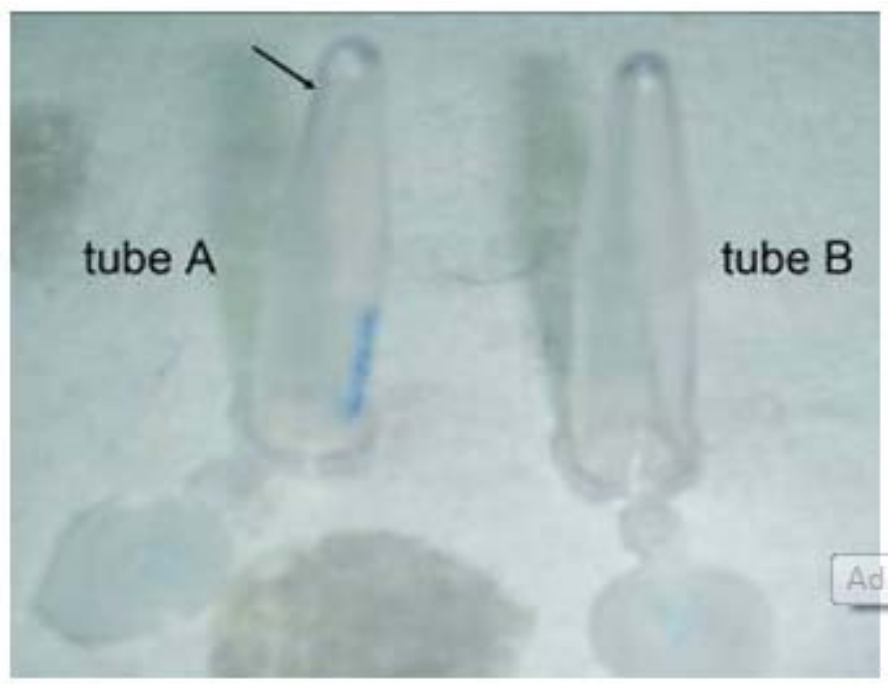

Fig. 2 The tubes after deposit during the experiment. After deposit with isopropyl alcohol and in hypothermia of $-70^{\circ} \mathrm{C}$, significant difference occurred between tube A (control group) and tube B (experimental group). There is abundant sedimentation on the inner wall in tube $\mathrm{A}$ (indicated by an arrow) while a little translucent deposition on the inner wall in tube $B$. 


\section{Agarose gel electrophoresis}

The extracted RNA was analyzed by agarose gel electrophoresis (Figure 3). 5M potassium acetate was added in tube $B$ while $0.1 \%$ DEPC-treated water in tube A as a control. There were obvious bands from the product of tube $B$, while from the product of tube $A$, there was hardly any band which could be seen clearly.

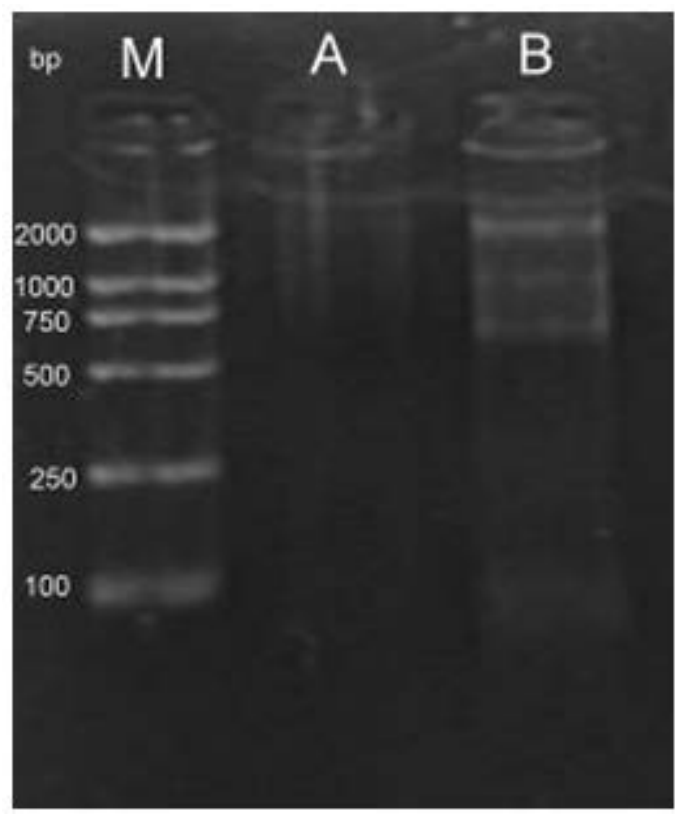

Fig. 3 Analysis of RNA by agarose gel electrophoresis. M: DNA Marker (DL 2000, TaKaRa); A: substance in tube A (control group); B: substance in tube B (experimental). On direct observation, bright bands can hardly be seen on the line of tube $A$, while there are three obvious bands on the line of tube $B$.

\section{UV ratio test}

At the observation of statistics, three repetitive test of substance in tube A showed that $260 / 280 \mathrm{~nm}$ ratio value (tube $A$ ) was far from the regular range of RNA ratio value between 1.8 and 2.0. On the other hand, three repetitive test of substance in tube B showed that $260 / 280 \mathrm{~nm}$ value are all in the regular range of RNA ratio value (tube $B$ ) (Table 2).

Table 2. Analysis of RNA by $\mathbf{2 6 0 / 2 8 0} \mathrm{nm}$ Ratio. After proofread with $0.5 \mu \mathrm{l}$ of $0.1 \%$ DEPC-treated water, the substance in tube $A$ were tested three times with one time on $0.5 \mu \mathrm{l}$ so as to tube B. Statistics showed that ratio value regarded to tube $A$ is lower than the normal range of RNA ratio value (1.8-2.0). Yet ratio value in tube $B$ is in normal range of RNA ratio value.

\begin{tabular}{ccccc}
\hline Sample ID & Abs at 260 $\mathbf{~ m}$ & Abs at $\mathbf{2 8 0} \mathbf{~ n m}$ & Bkg at 320 $\mathbf{~ m ~}$ & Ratio 260/280 \\
\hline water & 0.0002 & 0 & 0.0001 & -2.2342 \\
\hline Tube B-1 & 0.5120 & 0.2829 & 0.0315 & 1.9116 \\
\hline Tube B-2 & 0.5127 & 0.2830 & 0.0317 & 1.9142 \\
\hline Tube B-3 & 0.5127 & 0.2832 & 0.0318 & 1.9132 \\
\hline Tube A-1 & 3.1563 & 2.4337 & 0.0696 & 1.3056 \\
\hline Tube A-2 & 3.4921 & 2.4870 & 0.0679 & 1.4155 \\
\hline Tube A-3 & 3.4921 & 2.4776 & 0.0678 & 1.4210 \\
\hline
\end{tabular}




\section{Reverse transcription and PCR cloning}

Based on the observation of electrophoretogram, ubiquitin conjugating enzyme E2 gene and $\beta$-actin gene related straps both showed difference in the contrast between experimental group and control group. The experimental group A had only blurry straps on region of expected size. However, the experimental group B showed evident straps on the region (Figure 4). The amplified sequence length of ubiquitin gene is $430 \mathrm{bp}$ and the length of $\beta$-actin gene is $449 \mathrm{bp}$, which were also verified with sequencing.

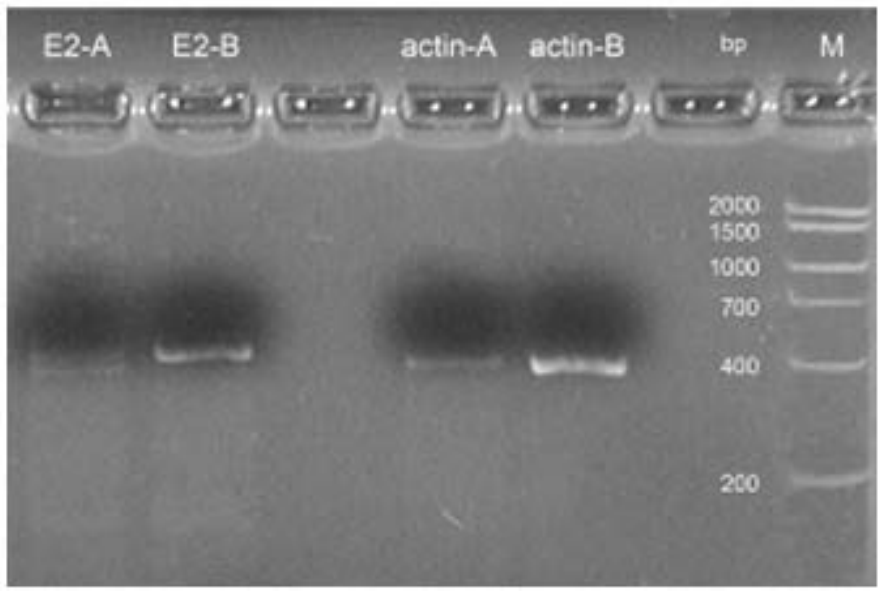

Fig. 4 Analysis of reverse transcription PCR product by agarose gel electrophoresis. E2-A: substance in tube A (control group) with ubiqutin conjugating enzyme E2 primers; E2-B: substance in tube B (experimental) with ubiquitin conjugating enzyme E2 primers; actin-A: substance in tube $A$ with $\beta$-actin primers; actin-B: substance in tube B with $\beta$-actin primers; M: DNA Marker (MD105, TianGen).

\section{DISCUSSION}

Total RNA extraction of optic stalks is a primary work for the research of S. paramamosain, and one major problem in the experiment is RNase which pervades in atmosphere and enriched in human body So, as employed in most laboratory, the whole experiment was processed in ventilation with medical gloves and masks to insulate the source of RNase from atmosphere and human body. All equipment which contacted stalk tissue or reaction system was RNase free. Also, in this study the centrifuge tubes were kept at $-70^{\circ} \mathrm{C}$ to ensure the stabilization of RNA.

Trizol method is widely used in RNA extraction of S. paramamosain on diverse organism (Imjongjirak et al. 2009; Liu et al. 2010; Xu et al. 2011), and RNA isolation of its close relative S. serrata was based on thiocyanate method which is the dominant ingredient of trizol reagent (Vaseeharan et al. 2007). Yet optic stalk of S. paramamosain is covered with carapace and in ordinary trizol method, there exists abundant impurity on production. In previous report, RNA isolation in some plants which enriched in polysaccharide has been proved as the additional acetate (Malnoy et al. 2001; Zeng and Yang, 2002; Vasanthaiah et al. 2008) in the reaction system to prevent the precipitation of polysaccharide. One major constitution of carapace is chitin, a sort of glucan polysaccharide (Djunaidah et al. 2003). As sedimentation concealed in the supernatant phase (supernatant phase generated after the step of adding chloroform and centrifuge at $4^{\circ} \mathrm{C}$ for $15 \mathrm{~min}$ ) and supernatant phase has solvent $0.1 \%$ DEPCtreated water, this kind of deposition should be some degree of dissoluble. Hence, it supported the hypothesis of the sedimentation as polysaccharide which is dissoluble in some degree. According to the result revealed by this study, high saline aroused by potassium acetate acted a significant role in dissolving polysaccharide such as chitin. In treating with RNA from crustacean such as $S$. paramamosain, it might be an efficient method by adding potassium acetate to separate chitin from RNA deposition. 
In this experiment, three different methods were employed to examine the distinction between traditional instructor and modified protocol. The agarose gel electrophoresis suggested that there be nucleotide in the extraction via modified protocol and there hardly be nucleotide in the extraction via inhered instructor; the UV ratio test indicated that the ingredient of extraction through modified protocol has nucleotide and there hardly be nucleotide in ingredient of extraction through inhered protocol.

In the examination with detection of reference genes (Imjongjirak et al. 2009), the bands had obviously shown that there existed RNA in the extraction by meliorated method yet there existed tiny nucleotide residue with traditional method. So, the modified protocol was feasible in isolating total RNA from optic stalks of S. paramamosain. However, the chemical mechanism of the method and the feasibility to other crustaceans is currently untested; the hypothesis of the cause correlated with deposition in traditional method is also another question. Hence, the ensuing interest will be focused on these problems and try to find the mechanism and relationship in them.

Financial support: National Natural Science Foundation of China (No. 31101890), Science and Technology Commission of Shanghai Municipality (No. 10JC1418600), and the Basic Research Fund for State-level Nonprofit Research Institutes of ESCFRI, CAFS (No. 2008M02, 2007Z01, 2007M22).

\section{REFERENCES}

BOVÉE, J.V.M.G.; BAELDE, H.J.; VAN BEERENDONK, H.M.; NAMBA, M.; CLETON-JANSEN, A.-M. and HOGENDOORN, P.C.W. (2001). High quality RNA isolation from tumours with low cellularity and high extracellular matrix component for CDNA microarrays: Application to chondrosarcoma. Journal of Clinical Pathology, vol. 52, p. 778-782. [CrossRef]

CHADDERTON, T.; WILSON, C.; BEWICK, M. and GLÜCK, S. (1997). Evaluation of three rapid RNA extraction reagents: Relevance for use in RT-PCR's and measurement of low level gene expression in clinical samples. Cell Molecular Biology, vol. 43, no. 8, p. 1227-1234.

CHANG, E.S. (1993). Comparative endocrinology of molting and reproduction: Insects and crustaceans. Annual Review of Entomology, vol. 38, p. 161-180. [CrossRef]

CHIRGWIN, J.M.; PRZYBYLA, A.E.; MACDONAD R.J. and RUTTER, W.J. (1979). Isolation of biologically active ribonucleic acid from sources enriched in ribonuclease. Biochemistry, vol. 18, no. 24, p. 5294-5299. [CrossRef]

DAHDOUH-GUEBAS, F.; COLLIN, S.; SEEN, D.L.; RÖNNBÄCK, P.; DEPOMMIER, D.; RAVISHANKAR, T. and KOEDAM, N. (2006). Analysing ethnobotanical and fishery-related importance of mangroves of the EastGodavari Delta (Andhra Pradesh, India) for conservation and management purposes. Journal of Ethnobiology and Ethnomedicine, vol. 2, p. 24-45. [CrossRef]

DE KLEIJIN, D.P.V.; JANSSEN, K.P.C.; WADDY, S.L.; HEGEMAN, R.; LAI, W.Y.; MARTENS, G.J.M. and VAN HERP, F. (1998). Expression of the crustacean hyperglycaemic hormones and gonad-inhibiting hormone during the reproductive cycle of the female American lobster Homarus americanus. Journal of Endocrinology, vol. 156, p. 291-298. [CrossRef]

DJUNAIDAH, I.S.; WILLE, M.; KONTARA, E.K. and SORGELOOS, P. (2003). Reproductive performance and offspring quality in mud crab (Scylla paramamosain) broodstock fed different diets. Aquaculture International, vol. 11, p. 3-15.

GEHRIG, H.H.; WINTER, K.; CUSHMAN, J.; BORLAND, A. and TAYBI, T. (2000). An improved RNA isolation method for succulent plant species rich in polyphenols and polysaccharides. Plant Molecular Biology Reporter, vol. 18, no. 4, p. 369-376. [CrossRef]

GU, P.L.; YU, K.L. and CHAN, S.M. (2000). Molecular characterization of an additional shrimp hyperglycemic hormone: cDNA cloning, gene organization, expression and biological assay of recombinant proteins. FEBS Letters, vol. 472, no. 1, p. 122-128. [CrossRef]

HSU, Y.W.A.; WELLER, J.R.; CHRISTIE, A.E. and DE LA IGLESIA, H.O. (2008). Molecular cloning of four cDNAs encoding prepro-crustacean hyperglycemic hormone $(\mathrm{CHH})$ from the eyestalk of the red rock crab Cancer productus: Identification of two genetically encoded $\mathrm{CHH}$ isoforms and two putative post-translationally derived $\mathrm{CHH}$ variants. General and Comparative Endocrinology, vol. 155, no. 3, p. 517-525. [CrossRef]

IMJONGJIRAK, C.; AMPARYUP, P.; TASSANAKAJON, A. and SITTIPRANEED, S. (2009). Molecular cloning and characterization of crustin from mud crab Scyllaparamamosain. Molecular Biology Reports, vol. 36, no. 5, p. 841-850. [CrossRef]

LIAO, Z.H.; CHEN, M.; GUO, L.; GONG, Y.F.; TANG, F.; SUN, X.F. and TANG, K.X. (2004). Rapid isolation of highquality total RNA from Taxus and Ginkgo. Preparative Biochemistry \& Biotechnology, vol. 34, no. 3, p. 209214. [CrossRef]

LIU, H.P.; CHEN, R.Y.; ZHANG, M. and WANG, K.J. (2010). Isolation, gene cloning and expression profile of a pathogen recognition protein: A serine proteinase homolog $(\mathrm{Sp}-\mathrm{SPH})$ involved in the antibacterial response in the crab Scylla paramamosain. Developmental \& Comparative Immunology, vol. 34, no. 7, p. 741-748. [CrossRef] 
MALNOY, M.; REYNOIRD, J.P.; MOURGUES, F.; CHEVREAU, E. and SIMONEAU, P. (2001). A method for isolating total RNA from pear leaves. Plant Molecular Biology Reporter, vol. 19, no. 1, p. 69. [CrossRef]

NAKATSUJI, T.; LEE, C.Y. and WATSON, R.D. (2009). Crustacean molt-inhibiting hormone: Structure, function, and cellular mode of action. Comparative Biochemistry and Physiology, Part A: Molecular \& Integrative Physiology, vol. 152, no. 2, p. 139-148. [CrossRef]

NICOLAIDES, N.C. and STOECKERT, C.J. (1990). A simple, efficient method for the separate isolation of RNA and DNA from the same cells. Biotechniques, vol. 8, no. 2, p. 154-156.

RAI, V.; GHOSH, J.S. and DEY, N. (2010). Isolation of total RNA from hard bamboo tissue rich in polyphenols and polysaccharides for gene expression studies. Electronic Journal of Biotechnology, vol. 13, no. 5. [CrossRef]

RUBIO-PIÑA, J.A. and VÁZQUEZ-FLOTA, F.A. (2008). Isolation of functional total RNA from Argemone mexicana tissues. Electronic Journal of Biotechnology, vol. 11, no. 4. [CrossRef]

RUBIO-PIÑA, J.A. and ZAPATA-PÉREZ, O. (2011). Isolation of total RNA from tissues rich in polyphenols and polysaccharides of mangrove plants. Electronic Journal of Biotechnology, vol. 14, no. 5. [CrossRef]

TSAI, K.W.; CHANG, S.J.; WU, H.J.; SHIH, H.Y.; CHEN, C.H. and LEE, C.Y. (2008). Molecular cloning and differential expression pattern of two structural variants of the crustacean hyperglycemic hormone family from the mud crab Scylla olivacea. General and Comparative Endocrinology, vol. 159, no. 1, p. 16-25. [CrossRef]

UDOMKIT, A.; CHOOLUCK, S.; SONTHAYANON, B. and PANYIM, S. (2000). Molecular cloning of a cDNA encoding a member of $\mathrm{CHH} / \mathrm{MIH} / \mathrm{GIH}$ family from Penaeus monodon and analysis of its gene structure. Journal of Experimental Marine Biology and Ecology, vol. 244, no. 1, p. 145-156. [CrossRef]

VASEEHARAN, B.; LIN, Y.C.; KO, C.F.; CHIOU, T.T. and CHEN, J.C. (2007). Molecularcloning and characterisation of a thioester-containing a2-macroglobulin ( $\alpha 2-\mathrm{M})$ from the haemocytes of mud crab Scylla serrata. Fish \& Shellfish Immunology, vol. 22, no. 1-2, p. 115-130. [CrossRef]

VASANTHAIAH, H.K.N.; KATAM, R. and SHEIKH, M.B. (2008). Efficient protocol for isolation of functional RNA from different grape tissue rich in polyphenols and polysaccharides for gene expression studies. Electronic Journal of Biotechnology, vol. 11, no. 3. [CrossRef]

XU, W.F.; QIAO, K.; HUANG, S.P.; PENG, H.; HUANG, W.S.; CHEN, B.; CHEN, F.Y.; BO, J. and WANG, K.J. (2011). Quantitative gene expression and in situ localization of scygonadin potentially associated with reproductive immunity in tissues of male and female mud crabs, Scylla paramamosain. Fish \& Shellfish Immunology, vol. 31, no. 2, p. 243-251. [CrossRef]

ZENG, C.S. and LI, S.J. (1999). Effects of density and different combinations of diets on survival development, dry weight and chemical composition of larvae of the mud crab Scylla paramamosain. In: KEENAN, C. and BLACKSHAW, A. eds. Mud Crab Aquaculture and Biology. Canberra, Australia, p. 159-166.

ZENG, Y. and YANG, T. (2002). RNA isolation from highly viscous samples rich in polyphenols and polysaccharides. Plant Molecular Biology Reporter, vol. 20, no. 4, p. 417. [CrossRef]

\section{How to reference this article:}

ZHU, H.; JIANG, K.; ZHANG, F.; ZHANG, D.; PI, Y. and MA, L. (2012). Improved isolation of good-quality total RNA from the optic stalk of Mud crab, Scylla paramamosain. Electronic Journal of Biotechnology, vol. 15, no. 2, p. 1-8. http://dx.doi.org/10.2225/vol15-issue2-fulltext-7 